\title{
ZONING AGAINST THE PUBLIC WELFARE: JUDICIAL LIMITATIONS ON MUNICIPAL PAROCHIALISM*
}

IN allocating the land resources of a municipality a zoning ordinance will generally prohibit certain uses deemed objectionable or incompatible. ${ }^{1}$ On occasion, uses so excluded-whether hospitals, ${ }^{2}$ churches, ${ }^{3}$ schools, ${ }^{4}$ homes for children, ${ }^{5}$ or universities ${ }^{6}$-are of such demonstrable social utility that the courts will not tolerate their exclusion. That the community's conception of the public welfare might on occasion be too parochial was foreseen by the Supreme Court in Village of Euclid v. Ambler Realty Co. ${ }^{7}$ in a statement which indicates that zoning contrary to a larger public interest would constitute a basis for invalidating an ordinance:

*Wiltwyck School for Boys, Inc. v. Perry, 14 App. Div. 2d 198, 219 N.Y.S.2d 161 (1961).

1. Village of Euclid v. Ambler Realty Co., 272 U.S. 365, 388-90 (1926).

2. American University v. Prentiss, 113 F. Supp. 389 (D.D.C. 1953); San Diego Tuberculosis Ass'n v. City of East San Diego, 186 Cal. 252, 200 Pac. 393 (1921) ; Ex parte Whitwell, 98 Cal. 73, 32 Pac. 870 (1893) ; Jewish Consumptives' Relief Soc'y v. Town of Woodbury, 230 App. Div. 228, 243 N.Y. Supp. 686 (1930), aff'd, 256 N.Y. 619, 177 N.E. 165 (1931).

3. Board of Zoning Appeals of Decatur v. Decatur, Indiana Co. of Jehovah's Witnesses, 233 Ind. 83, 117 N.E.2d 115 (1954) ; Mooney v. Orchard Lake, 333 Mich. 389, 53 N.W.2d 308 (1952) ; Congregation Temple Israel v. City of Creve Coeur, 320 S.W.2d 451 (Mo. 1959); State ex rel. Synod of Ohio v. Joseph, 139 Ohio St. 229, 39 N.E.2d 515 (1942); State e.t rel. Anshe Chesed Congregation v. Bruggemeier, 97 Ohio App. 67, 115 N.E.2d 65 (1953) ; Garden City Jewish Center v. Garden City, 2 Misc. 2d 1009, 155 N.Y.S.2d 523 (Sup. Ct. 1956), appeal dismissed, 157 N.Y.S.2d 435 (1956).

4. City of Chicago v. Sachs, 1 Ill. 2d 342, 115 N.E.2d 762 (1953) ; Catholic Bishop of Chicago v. Kingery, 371 Ill. 257, 20 N.E.2d 583 (1939) ; State v. Northwestern Preparatory School, 228 Minn. 363, 37 N.W.2d 370 (1949); Lumpkin v. Township Committee, 134 N.J.L. 428, 48 A.2d 798 (1946); Diocese of Rochester v. Planning Bd., 1 N.Y. 2d 508, 136 N.E.2d 827, 154 N.Y.S.2d 849 (1956); Brandeis School v. Lawrence, 18 Misc. 2d 550, 184 N.Y.S.2d 687 (1959).

5. University Heights v. Cleveland Jewish Orphans' Home, 20 F.2d 743 (8th Cir.), cert. denied, 275 U.S. 569 (1927) ; Rogers v. Association For the Help of Retarded Children, 308 N.Y. 126, 123 N.E.2d 806 (1954); Franciscan Missionaries of Mary v. Herdman, 7 App. Div. 2d 993, aff'd without opintion, 7 N.Y. 2d 829 (1959); City of Rochester v. Rochester Girls' Home, 194 N.Y. Supp. 236 (1922) ; Walker v. Zoning Bd. of Adjustment, 380 Pa. 228, 110 A.2d 414 (1955).

6. American University v. Prentiss, 113 F. Supp. 389 (D.D.C. 1953); Western Theological Seminary v. City of Evanston, 325 Ill. 511, 156 N.E. 778 (1927), aff'd, 333 I11. 257, 162 N.E. 863 (1927); Long Island University v. Tappan, 202 Misc. 956, 113 N.Y.S.2d 795 (Sup. Ct. 1952), aff'd, 305 N.Y. 893, 114 N.E.2d 432 (1953); Concordia Collegiate Institute v. Miller, 301 N.Y. 189, 93 N.E.2d 632 (1950); Hofstra College v. Wilmerding, 24 Misc. 2d 248, 204 N.Y.S.2d 476 (1960), appeal dismissed, 12 App. Div. 2d 631, 210 N.Y.S.2d 791 (1960).

7. 272 U.S. $365(1926)$. 
It is not meant by this . . . to exclude the possibility of cases where the general public interest would so far outweigh the interest of the municipality that the municipality would not be allowed to stand in the way. ${ }^{8}$

In a recent case, Wiltwyck School for Boys, Inc. v. Perry, ${ }^{9}$ the Appellate Division of the New York Supreme Court upheld the validity of an amended zoning ordinance which excluded a use of uncontested social utility. ${ }^{10}$ Wiltwyck maintains a home in up-state New York for roughly one-hundred neglected and delinquent boys, aged eight to twelve, who are referred by New York City welfare and correctional agencies. ${ }^{11}$ The home provides individual therapy, extensive recreation and formal schooling at a public school operated and staffed by the New York City Board of Education on Wiltwyck's grounds. ${ }^{12}$ Because of its location 110 miles from New York City, Wiltwyck has experienced great difficulty in recruiting residential staff and in utilizing its part-time commuting personnel with maximum efficiency. ${ }^{13}$ After the enactment of municipal ordinances had thwarted two prior attempts to locate closer to New York City, ${ }^{14}$ Wiltwyck purchased an estate in Yorktown, an outlying suburb. ${ }^{15}$ It was refused a building permit, however, on the ground that the proposed use was proscribed by an amendment to the town's zoning ordinance. ${ }^{16}$ This amendment-which was enacted immediately after Wiltwyck had completed the purchase ${ }^{17}$-prohibited the location of certain types of charitable institutions within Yorktown. ${ }^{18}$ Wiltwyck sought to compel is-

8. Id. at 390. See also State ex rel. Synod of Ohio v. Joseph, 139 Ohio St. 229, 39 N.E.2d 515, $522(1942)$ :

The Village of Euclid case, while deciding that commercial and industrial structures may, consistently with the Fourteenth Amendment, be excluded from residential districts, decides nothing with regard to the exclusion of humanitarian, public and semi-public uses like churches, schools and libraries.

9. 14 App. Div. 2d 198, 219 N.Y.S.2d 161 (1961).

10. Record, pp. 66-67, 257-58, Wiltwyck School for Boys, Inc. v. Perry, 14 App. Div. 2d 198, 219 N.Y.S.2d 161 (1961).

11. Record, pp. 9-13.

12. Ibid.

13. Id. at $19-20$.

14. Letter from Harry G. Liese to the Yalc Law Journal, December 13, 1961. (On file in Yale Law Library.)

15. Record, p. 13.

16. Id. at $17-18$.

17. Id. at 13, 20-21.

18. Id. at 21. Building Ordinance of Yorktown. Section 220 of Art. II, defines "Charitable Institution" as follows:

A place, building or structure designed or used for any of the following purposes: Home for the Aged.

Orphanage operated as an accessory use to a religious institution all of which are operated on a non-profit basis and supported and financed solely by charitable funds; an extension of welfare uses and research for the public health in existence in the town prior to the date this amendment becomes effective, and operated on a nonprofit basis and supported and financed solely by public or charitable funds.

Eleemosynary Institutions.

Same as charitable institutions as defined herein. 
suance of the building permit on two grounds: first that it was not a treatment center, but a school and therefore a permitted use under the ordinance as amended; and second, that the ordinance if construed to bar institutions such as Wiltwyck was invalid because it conflicted with an express policy of the state providing for the support and welfare of delinquent and neglected children. ${ }^{10}$ The Appellate Division rejected both contentions. ${ }^{20}$

The decision may be considered as representing a routine application of the general principle that a court "does not sit as a super-zoning commission," 21 and that given a reasonable basis for a contested provision, a court, out of deference to the legislature, will uphold its validity. ${ }^{22}$ This position is grounded in considerations of propriety and competency..$^{23}$

Propriety: Advocates of this approach argue that absent a clear legislative mandate, a court should not impose its preference for a particular land use on a municipality. Adjustments between conflicting demands for the use of land are matters for political action, not judicial fiat. This is particularly true when, as in the case of Wiltwyck, a use which services the metropolitan area, wishes to locate in the suburbs. Legislatures, not courts, are the proper area for the struggle between the suburb and the metropolitan areas. ${ }^{24}$

Competency: It is further contended that a court should not substitute its judgment for that of the professional planning staff because it lacks the in-

19. These were the principal arguments dealt with in the decisions of the Appellate Division, 14 App. Div. 2d 198, 219 N.Y.S.2d 161 (1961). Wiltwyck also contended that the ordinance as amended deprived it of the equal protection of the law in that there was no reasonable basis for the classification created by the Yorktown amendment. In permitting only homes for the aged and orphanages operated as an accessory use to religious institutions, the amendment excluded such uses as non-denominational orphanages, homes for cardiac children, for victims of cerebral palsy, etc. The distinction is as reasonable and achieves the same effect as if it had read "All charities beginning with 'W' are hence barred from Yorktown." See Decision by Mr. Justice Coyle, New York Law Journal, April 15, 1960, reprinted in Record, pp. 328-34.

20. Wiltwyck School for Boys, Inc. v. Perry, 14 App. Div. $2 d$ 198, 219 N.Y.S.2d 161 (1961).

21. Robinson v. City of Bloomfield Hills, 350 Mich. 425, 430, 86 N.W.2d 166, 169 (1957).

22. Village of Euclid v. Ambler Realty Co., 272 U.S. 365, 387-88 (1926).

23. Haar, Regionalism and Realism in Land-Use Planing, 105 U. PA. L. REv. 515, $530-33$ (1957) ; Robinson v. City of Bloomfield Hills, 350 Mich. 425, 430, 86 N.W.2d 166, 169 (1957).

24. In the phases of urban life and activity in which I have worked most during the last twenty years-urban planning, housing and redevelopment-I find it hard to escape the conclusion that the trend is on the whole against or away from mutual understanding, respect and trust across group and class lines.... [Z]oning ordinances have had a major influence in [this] direction. This influence seems to increase as the amendment and redrafting of ordinances add more and more finely drawn use districts. The common sense observation that slaughter houses and stamping mills should not be located next to dwellings or hospitals has been gradually extended to justify and support an increasing amount of segregation among various kinds of residential development.

Woodbury, The Background and Prospects of Urban Redevelopment in the Unitcd States, in The Future of Cities and Urban Redeveloparent 634-35 (Woodbury ed. 1953). 
formation and expertise to evaluate the increasingly complex considerations which underlie each zoning provision. The issue of competency is particularly critical when a court is asked to determine whether alternate suitable sites exist. This determination may be necessary where it is alleged that the exclusion of a particular use from one locality subverts a state policy. If the prohibited use could function as effectively on an alternate and available site, the decision of one community to exclude the use would not actually thwart state policy. And to determine whether alternate sites exist, a court would have to construct a regional picture of available sites from a complex of land use maps and real estate data. Even if the courts were equal to this task, they would be unable to predict the response of other localities should the excluded use seek to locate within their bounds. ${ }^{25}$

These considerations are urged in support of non-judicial resolution of the conflicts generated between state and locality, city and suburb regarding the location of institutions like Wiltwyck. ${ }^{28}$ Three distinct types of such solutions would enable authorities to override parochial interests in allocating land for uses which service the larger region. First, local governmental bodies could create an area of political control coextensive with the needs of a functionally defined geographic area. ${ }^{27}$ Second, the state legislature could create a planning board with power to allocate resources on a state-wide basis in conformity with a comprehensive master plan. ${ }^{28}$ Third, the plight of specific institutions, such as hospitals, sanitariums, schools and private utilities, can be relieved by special legislation authorizing the use of eminent domain on their behalf. ${ }^{29}$

A variant on the delegation of eminent domain utilized by New York State on behalf of private tuberculosis sanitariums appears particularly applicable to the

25. In Wiltwyck's case, such a prediction would have been of particular importance in determining the existence of alternate available sites. Yorktown was the third municipality to respond to Wiltwyck's location efforts with an exclusionary amendment to the zoning law. Presumably further such responses might have occurred wherever Wiltwyck attempted to buy an estate. Letter from Harry G. Liese to the Yale Lazes Journal, December 13, 1961. (On file in the Yale Law Library.)

26. Haar, sitpra note 23 , at 530-37.

27. The means tried and proposed include: annexation of unincorporated territory, consolidations of two or more municipalities, city-county consolidation, intergovernmental agreements, special districts and authorities. See generally Webster, Urban Planning and Municipal Public Policy 55-76 (1958); McDougal \& Haber, Property, Wealte, Land: Allocation, Planning and Developarent 751-66, 980-81 (1948). See generally $A$ Symposium on Metropolitan Regionalism: Developing Governmental Concepts, 105 U. PA. L. Rev. 439-616 (1957).

28. See Haar, silpra note 23 , at 531-35.

29. Several approaches are possible: (1) granting the appropriate state agency the power to condemn land for an institution. See Brent v. Hoch, 25 Misc. 2d 1062, 205 N.Y.S.2d 66 (Sup. Ct. 1960), aff'd, 13 App. Div. 2d 505, 211 N.Y.S.2d 853 (1961), construing N.Y. Mrental Hygiene ACT \& 46(1); or (2) granting the power of eminent domain to the private party subject to review of the reasonableness of its exercise by the appropriate administrative agency. See In re Hackensack Water Co., 41 N.J. Super. 408 (App. Div. 1956), construing N.J. REv. STAT. § 40:55-50 (1928). 
Wiltwyck situation. ${ }^{30}$ The state could bestow on Wiltwyck and similar institutions a statutory grant of immunity exempting them from the application of local zoning ordinances. A use receiving such immunity would not possess the power to condemn, but once having found a willing seller, it could purchase and utilize the land subject only to review by appropriate state officials. This would not run afoul of the "public use" standard for eminent domain. ${ }^{31}$ The state, in effect, is merely withdrawing part of the police power it delegated to municipalities when it authorized them to pass zoning ordinances.

Whether or not it is believed that the foregoing legislative solutions would constitute the most desirable way of adjusting and preventing disputes such as that posed in the Wiltwyck case, such solutions may be long in coming. ${ }^{32}$ Suburban communities are especially loth to enter any scheme of cooperation which entails their shouldering a larger share of the costs of urban services, either directly, through taxes, or indirectly, through being compelled to accommodate additional tax-free institutions. ${ }^{33}$ Similarly, suburban dwellers are reluctant to subject themselves to the decisions of a metropolitan or state planning board which might subordinate their interests to the often conflicting interests of the urban or rural areas. ${ }^{34}$ Finally, unless institutions like Wiltwyck gain considerably more political influence, it is highly unlikely that they will overcome the traditional reluctance of state legislatures to enact legislation granting the power of eminent domain or zoning immunity to private interests. $^{35}$

In the absence of a legislative resolution, institutions such as Wiltwyck have turned to the courts for remedial action. And courts have frequently recognized the necessity of protecting institutions which serve a larger public interest from the operation of local zoning ordinances. ${ }^{36}$ In so doing, they customarily utilize three techniques, any of which would have enabled the

30. See Jewish Consumptives' Relief Soc'y v. Town of Woodbury, 230 App. Div. 228, 243 N.Y. Supp. 686 (1930), aff'd, 256 N.Y. 619, 17 N.E. 165 (1931), construing N.Y. PubLIC HeALTh LAW §§ 2269-70.

31. Private universities, lodges, Chatauqua and churches have consistently been denied the right to employ the power of eminent domain because this power can only be exercised for a "public purpose" and courts have frequently construed this phrase to mean "use by the public." 2 Nichols, Earinent Dodrain $\$ \$ 7.2(1), 7.517$ (3d ed. 1950).

32. See generally Moak, Somc Practical Obstacles in Modifying Gozcrmmental Structure to Meet Metropolitan Problems, 105 U. PA. L. REv. 603 (1957).

33. Id. at 611-12.

34. The Future of Cities and Urban Redevelopment 501 n.39 (Woodbury ed. 1953).

35. See note 31 supra.

36. See cases cited notes 2-6 supra. The dilemma of the courts has been put thus in Niagara Mohawk Power Corp. v. City of Fulton, 8 App. Div. 2d 523, 529, 188 N.Y.S.2d 717, 723-24 (1959):

The situation created by the failure of the local legislative body to provide for necessary public utility structures is, at best, an unsatisfactory one. The questions involved in the selection of a site ought to be determined by a legislative or administrative body rather than by the courts .... Where no legislative provisions of this character exist, the task must be undertaken by the courts and the courts must do 
Appellate Division to decide in favor of Wiltwyck. First, a court may feel impelled by reason of public policy to expand by construction one of the categories of permitted uses to include an apparently excluded party..$^{37}$ Secondly, it may extend the governmental immunity possessed by a public institution to private institutions carrying out similar functions on grounds that no reasonable basis for differential treatment can be found. ${ }^{38}$ And third,

the best they can in determining whether the use of the particular proposed site is reasonably necessary, in the light of all the factors bearing upon that question.

Charles M. Haar describes the situation accurately when he says that courts "have been plunged into the vacuum of power" resulting from the lack of any comprehensively oriented state or municipal planning agency whose jurisdiction corresponded to the dimensions of a functionally interdependent area. Haar, supra note 23, at 536. And while he argues properly that courts "do not seem the most desirable focus for resolving inter-community conflicts or promoting regional land development" he concedes that "absent some other agency for the resolution of this type of dispute" the influence of the courts is likely to grow. Haar, sipra note 23 , at 527. "If . . . other governmental agencies default, certainty as well as the need to come to a final decision may be as important as the merits of the particular decision." Haar, supra note 23 , at 531.

37. The courts do not explicitly acknowledge that policy reasons lie behind their decision that the excluded institution should be included within the category of permitted uses as judicially defined. Nonetheless, the mention of policy considerations which are almost unfailingly present in these cases leads one to suspect a causal connection. The following statement is representative of the intermingling of policy considerations in the process of defining the category of permitted uses:

As to plaintiffs' claim that the use to which the prior owner put the property had been a convalescent home and not a school, we think the argument disregards both the statutory requirement last cited above, and the strong public policy of the state which favors the education of all children, however handicapped.

Rogers v. Association for the Help of Retarded Children, 308 N.Y. 126, 132, 123 N.E.2d 802, 806 (1954). See also Langbein v. Board of Zoning Appeals, 135 Conn. 575, 67 A.2d 5 (1949); Livingston v. Davis, 243 Iowa 21,50 N.W.2d 592 (1951); Five Towns YM and YWHA, Inc. v. Plaut, 14 Misc. 2d 61, 178 N.Y.S.2d 190 (Sup. Ct. 1958), aff'd reithout opinton, 7 App. Div. 2d 646, 181 N.Y.S.2d 182 (1958) ; Merrick Community Nursery School v. Young, 11 Misc, 2d 576, 171 N.Y.S.2d 522 (Sup. Ct. 1958) ; People v. Collins, 191 Misc. 553, 83 N.Y.S.2d 124 (1948) ; City of Rochester v. Rochester Girls' Home, 194 N.Y. Supp. 236 (Sup. Ct. 1922) ; United Cerebral Palsy Ass'n v. Zoninz Bd. of Adjustment, $382 \mathrm{~Pa} .67$, 114 A.2d 331 (1955); Walker v. Zoning Bd. of Adjustment, 380 Pa. 228, 110 A.2d 414 (1955).

38. This technique is most commonly used in cases which involve the exclusion of private schools. The importance of private elementary and secondary schools in this country makes differential treatment contrary to public policy and this explains the overwhelming judicial opposition to excluding private schools. See Diocese of Rochester v. Planning Bd., 1 N.Y. $2 d$ 508, 154 N.Y.S.2d 849, 136 N.E.2d 827 (1956) and cases collected in Annot., 36 A.L.R.2d 653 (1954). Although most courts say that there is no reasonable basis for differential treatment, noting that private and public schools work the same detriment on the surrounding community, it is clear that policy considerations blind them to one distinction-namely, the nature of the service conferred on the public-which has been noted in two cases; State cx rel. Wisconsin Lutheran High School Conference v. Sinar, 267 Wis. 91, 65 N.W.2d 43 (1954) ; Great Neck Community School v. Dick, 140 N.Y.S.2d 221 (Sup. Ct. 1955), aff'd on other grounds, 3 App. Div. 2d 664, 158 N.Y.S.2d 379 (1957). This "use by the public" distinction has been utilized by the courts to deny the grant of eminent domain to a private college. Connecticut College for Women v. Calvert, 87 Conn. 421, 88 At1. 633 (1913). 
it may invalidate an ordinance because a certain use is so essential to the public welfare that an ordinance which excludes it can bear no reasonable relation to the public welfare. ${ }^{39}$ The first two techniques have been used by courts in a variety of familiar statutory contexts and present few novel issues. The third technique-which rests explicitly on considerations of state public policy-represents, perhaps, the most accurate description of why courts respond to the claims of an excluded use. As such, it is significant both in itself and also as a rationale for the application of the other two techniques. For purposes of analysis it will be treated as if it were the single basis for a court's decision.

The imprecision of a standard explicitly based on considerations of "public welfare" raises serious practical problems. If the standard to be applied is simply whether or not the excluded use is "clearly in furtherance of the public welfare," few uses could be excluded from even the most "exclusive" residential zones. ${ }^{40}$ Graveyards, garbage disposal units and heavy industry, for example, are indispensable to the health and welfare of a community. But it hardly follows that all such uses should be permitted in residential suburbs. ${ }^{41}$ Nor is the modification suggested by Judge Klienfeld-that the use "is under the direct supervision, care and concern of the State itself" 42 - sufficient to distinguish between uses which should or should not secure judicial protection. Virtually every industry, commercial enterprise, institution or organization can point to some federal or state policy which it advances subject to varying degrees of government control and assisted by various forms of federal or state subsidy. 43

Since the "public welfare" standard by itself provides no conceptually adequate criteria for limiting its application, any attempt to give meaning to

39. The statement made in Catholic Bishop v. Kingery, 371 Ill. 257, 259-60, 20 N.E.2d 583,584 (1939) is representative of the courts' manner of stating the issues of public policy:

As a matter of fact such a school, conducted in accordance with the educational requirements established by State educational authorities, is promotive of the general welfare.

See cases cited notes 2-6 supra. See also BASsetT, Zoning 70-79, 196, 198-200 (1940); In re O'Hara's Appeal, 389 Pa. 35, 131 A.2d 587 (1957). For reasons that will be seen, this third technique is always used in conjunction with the contention that the zoning provision in question violates the due process or equal protection clauses of the Constitution. Interference with the general rights of property owners can only be sustained if it bears "a substantial relation to the ... general welfare." Nectow v. City of Cambridge, 277 U.S. 183, 188 (1928). A restriction that is contrary to public policy will, by definition, bear no such substantial relationship and will therefore be invalid as arbitrary, confiscatory, or discriminatory.

40. Cf. 2 Nichols, Earinent Domain \$ 7.2(3) (3d ed. 1950).

41. Indeed, courts have frequently tolerated their total exclusion. Dufficon Concrete Prods., Inc. v. Borough of Cresskill, 1 N.J. 509, 64 A.2d 347 (1949) ; West Bloomfield Township v. Chapman, 351 Mich. 606, 88 N.W.2d 377 (1958); and see note 1 supra.

42. 219 N.Y.S.2d at $\mathbf{1 8 7}$ quoting Matter of Concordia Collegiate Institute v. Miller, 301 N.Y. 189, 195-96, 93 N.E.2d 632, 636 (1950) (dicta).

43. Cf. Eisenstein, The Ideologies of Taxation 143-46 (1961). 
the courts' articulation of this standard must begin with the observation that some notion of preferred institutions apparently underlies those zoning decisions immunizing private uses. ${ }^{44}$ These preferred uses may be described roughly as non-profit institutions devoted to medical, eleemosynary, religious or educational purposes. The equities are not always on the side of these preferred uses ${ }^{45}$ and such uses certainly do not always prevail in court. ${ }^{46}$ Thus, it becomes necessary to inquire what considerations have moved the courts to strike down zoning ordinances on grounds of public policy. ${ }^{47}$

44. In our economy, churches, schools, play grounds, and other community institutions occupy a very different status in the regulating aspect from purely business enterprises where people gather in companies. They have always been thought to be important assets to our cultural, social and moral needs....

State of Florida ex rel. Tampa Co. of Jehovah's Witnesses v. City of Tampa, 48 So. 2d 78, 79 (Fla. Sup. Ct. 1950). See also Matter of Concordia Collegiate Institute v. Miller, 301 N.Y. 189, 195-96, 93 N.E.2d 632, 635 (1950) :

In the case now before us, we are not dealing with billboards or garages or other offensive uses in connection with which consent provisions may be proper, but with an educational use which is clearly in furtherance of the health, safety, morals and general welfare of the community, and is under the direct supervision, care and concern of the State itself. Zoning ordinances must find their justification in the police power excrcised in the interest of the public.

The notion of preferred institutions may be translatable into a problem of demonstrating sufficient governmental concern: Is there a provision in the state or federal constitution which recognizes the function of the institution as being of special value to the state? Analytically, this restatement begs the question. Is the use preferred because it can point to a relevant constitutional provision; or is there a relevant constitutional provision because the use is preferred. If the latter, then we must ask why is it preferred. To answer this, it is necessary to state for what purposes the use is preferred and then it may be possible to suggest functional reasons for the preference. In the context of this Note, preference refers to the right of the institution to locate in a residential district, notwithstanding an exclusionary zoning ordinance. Preference for this purpose may be explained in terms of the general and specific environmental needs of the institution. See text accompanying notes 48-70 infra.

45. Some types of institutions, for example, no matter how salutory their purpose, work unreasonable hardships on a residential community (i.e., a trade school or maximum security prison). Cf. Kanasy v. Nugent, 206 Misc. 826, 135 N.Y.S.2d 12S (1954), aff'd, 286 App. Div. 1038, 145 N.Y.S.2d 638 (1955), appeal denied, 1 App. Div. 2d 681, 148 N.Y.S.2d 455 (1955). In addition, a municipality may need to maintain its dwindling supply of desirable residential land, not merely for tax purposes, but to prevent the continued exodus of that indigenous leadership upon which effective and far-sighted local government depends. See text at note 62 infra.

46. E.g., City of Chico v. First Ave. Baptist Church of Chico, 108 Cal. App. 2d 297, 238 P.2d 587 (1951); Sexton v. Bates, 17 N.J. Super. 246, 85 A.2d 833 (1951); In the Matter of Jewish Mental Health Soc'y v. Village of Hastings, 268 N.Y. 458,198 N.E. 30 (1935), modificd, 269 N.Y. 562 (1935), appeal dismissed, 297 U.S. 696 (1935), affirming 243 App. Div. 707, 277 N.Y. Supp. 989 (1935); Wiltwyck School for Boys, Inc. v. Perry, 14 App. Div. 2d 198, 219 N.Y.S.2d 161 (1961); Application of Devereux Foundation, Inc., 351 Pa. 47S, 41 A.2d 744, appeal disnissed, 326 U.S. 686 (1945).

47. It is not meant to imply that by enumerating certain considerations one can reconcile all existing case law. Irreconcilable inconsistencies are clearly present in some of these cases. 
It is submitted that the following three considerations operate as successive limitations on the extension of immunity to uses which challenge an ordinance on grounds of public policy: 1) general environmental requirements of the use; 2) the specific need to locate in a particular community; and 3 ) the detriment to the community in which it proposes to locate. These considerations, while not articulated by the courts as outcome determinative factors, do receive judicial recognition when courts attempt to sum up the most compelling aspects of the particular factual situation before them. To this extent, the court's preferences for certain types of institutions are circumscribed by factors which to a considerable degree are susceptible of empirical analysis.

\section{General Environmental Requirements}

A party challenging a zoning ordinance has the initial burden of demonstrating that location in the type of zone from which it has been excluded is essential rather than merely advantageous to the fulfillment of its service function. Unless the party can demonstrate this need, it has not been sufficiently injured to justify relief. Courts have tended to assume the essential need of hospitals, schools and churches to locate in otherwise restricted residential neighborhoods. ${ }^{48}$ The inappropriateness of available locations in less restricted commercial or industrial zones has been noted by the courts. ${ }^{49}$ In State ex rel. Synod of Ohio v. Joseph, ${ }^{50}$ for example, the court elaborated the functional need of the excluded church:

Fully to accomplish its great religious and social function, the church should be integrated into the home life of the community which it serves. Churches in fitting surroundings are an inspiration to their members and to the general public. If located in the residential district-space, perspective, greenswards and trees aid in setting off the beauty of the building and thereby increasing its inspiration. To require that churches be banished to the business district, crowded alongside filling stations

However, it is hoped that an inductive approach to cases involving "preferred institutions" will at once describe the vast majority of cases and will provide an analytical framewor': within which future cases can be handled in a consistent manner. To the extent that it is hoped that these considerations will be more clearly articulated and consciously applied in the future, the remaining discussion contains an avowedly normative element.

48. See Bassett, Zoning 70-73, 196-200 (1940) for the classic discussion of such institutions' functional needs. Courts often cite to Bassett rather than examining the particular facts of the case. E.g., Langbein v. Board of Zoning Appeals, 135 Conn. 575, 67 A.2d 5 (1949).

49. E.g., Livingston v. Davis, 243 Iowa 21, 29, 50 N.W.2d 592, 597 (1951) where the court noted :

It does not seem reasonable this zoning ordinance was intended to restrict such a use as defendants make of their property to an Industrial District. Certainly that would not be a suitable place for it.

And see O'Brien v. City of Chicago, 347 I1l. App. 45, 51, 105 N.E.2d 917, 920 (1952) where the court implied that a zoning ordinance could not force churches into sparsely inhabited areas.

50. 139 Ohio St. 229,39 N.E.2d 515 (1942). 
and grocery stores, is clearly not to be justified on the score of promoting the general welfare. 51

Application of this first consideration requires a decision as to how essential these environmental needs are. Often, there is no more ideal a location for a funeral parlor, drugstore, or delicatessen than a quiet, exclusive residential neighborhood. And conceivably a manufacturing concern could procure testimony from a battery of industrial psychologists that such an environment would inspire the research staff and increase productivity enormously. Obviously, the courts in distinguishing between an advantageous location and an essential one are considering the degree of impairment of the service offered by the use which will result if the use is excluded from this type of location. 52

\section{The Specific Need To Locate in a Particular Community}

To invalidate a zoning ordinance, an institution must do more than demonstrate that it needs to locate in a certain type of neighborhood; it must show specific need to locate in the particular community from which it has been excluded. In analyzing this second criterion, two groups of cases must be distinguished. The first and most common group involves uses which service the area in which they wish to locate and from which they have been excluded. Churches and private elementary or secondary schools are obvious examples of such uses. The second group involves uses which do not service the community in which they wish to locate. It is more difficult for such a use to establish the need to locate in any given community even though it is clear that because of its "general environmental needs" a suitable location cannot be found in the area which it services. ${ }^{53}$

A. Institutions serving the area from which excluded. In cases involving the exclusion of churches and privately operated elementary and secondary

51. 39 N.E.2d at 524 .

52. See State $\boldsymbol{e x}$ rel. Lake Drive Baptist Church v. Village of Bayside Bd. of Trustees, 12 Wis. 2d 585, 108 N.W.2d 288, 296 (1961) where the court said:

An ordinance which excludes a church from a particular district must pass two tests:

(1) Can it reasonably be said that use for a church would have such an effect on the area that exclusion of such use will promote the general welfare, and

(2) Does the exclusion impose a burden upon freedom of worship which is not commensurate with the promotion of general welfare secured?

See also Young Israel Organization v. Dworkin, 105 Ohio App. 89, 133 N.E.2d 174 (1956) where the court noted that because of religious restrictions on Sabbath activity, a place of worship for orthodox Jews must be within walking distance of their homes.

53. For instance, if a sanitarium, school or treatment center accepts only those persons who reside in a metropolitan area, barring topographical peculiarities, it may with equal convenience perform its services for that city while located in any of the suburbs within reasonable commuting distance from the city. Exclusion of the institution from one suburb works no hardships on the persons to be aided by the institution, if it can locate in another suburb as close to the area which it services. 
schools, courts are particularly sensitive to the claim that the rights of parties whom the institution serves have been infringed by the exclusionary zoning ordinance. Churches have been granted standing to assert the first amendment rights of parishioners ${ }^{54}$ and private schools have likewise been permitted to invoke the right of parents to send their children to the accredited school of their choice. ${ }^{55}$ Moreover, the courts do not inquire into how many persons' rights are impaired or how severe the impairment is even when most of the persons served live in another community. 56 Two explanations of why courts refuse to make this inquiry are possible. First, the future residential distribution of those whom the institution serves may be entirely different from that which presently exists. ${ }^{57}$ A church or school, anticipating a suburban migration, may wish to locate in advance of this shift while land is still available and cheap. A court promulgated rule that an institution can locate only where a certain percentage of its present clientele resides would straight-jacket the institution. Second, even if it be conceded that only a small number of residents presently are or in the future will be served, the courts will not consider this to be a valid basis for barring the use. They reason that insofar as many local residents attend, for example, churches or schools in neighboring communities, reciprocity demands that the entry of a use should not be prevented solely on the ground that it predominantly serves non-residents. ${ }^{58}$

B. Institutions which do not service the community in which they seck to locate. Wiltwyck provides an excellent example of such a use. In defending the propriety of its ordinance, Yorktown contended that the correct criterion to be applied to such uses was

whether or not locations that are suitable ... are available under the aggregate of existing zoning regulations .... ${ }^{50}$

Indeed, it is sensible to require a party having a choice of sites in two communities, one of which proscribes such uses, the other of which permits them,

54. Any restriction upon the opportunity to build a house of worship is at least a potential burden upon the freedom of those who would like to worship there. Whether the burden is slight or substantial will depend upon circumstances. In a community where adequate and accessible building sites are available in all districts, it might be a negligible burden to exclude churches from some of them. There must be many circumstances under which a religious group could demonstrate that an exclusion from a particular area would be a substantial burden.

State $e x$ rel. Lake Drive Baptist Church v. Village of Bayside Bd. of Trustees, 12 Wis. 2d 585,108 N.W.2d 288, 296 (1961). See also cases cited note 2 supra.

55. Pierce v. Society of Sisters, 268 U.S. 510 (1924). See also cases cited noted 4 supra.

56. E.g., Hofstra College v. Wilmerding, 24 Misc. 2d 248, 204 N.Y.S.2d 476, appcal dismissed, 12 App. Div. 2d 631, 210 N.Y.S.2d 791 (1960); Andrews v. Ocean Township, 30 N.J. 245 (1959); State $e x$ rel. Anshe Chesed Congregation v. Bruggemeier, 97 Ohio App. 67,115 N.E.2d 65 (1953).

57. Hofstra College v. Wilmerding supra note 56.

58. State ex rel. Anshe Chesed Congregation v. Bruggemeier, 97 Ohio App. 67, 115 N.E.2d 65 (1953).

59. Record, p. 263. 
to select a site in the latter community. ${ }^{00}$ The critical question, however, not ruled on by the court, involves the time at which the rule of "alternate unrestricted sites" should be applied: the date of purchase or the date of trial. ${ }^{61}$ It would seem both sensible and necessary to utilize the rule as being implicitly operative at the time of purchase, not at the time of trial. If the date of purchase is the applicable time, Wiltwyck made a reasonable choice when it declined to purchase land in two other communities which had already passed exclusionary zoning ordinances ${ }^{62}$ and completed the transaction in Yorktown where it was a permitted use when title passed. ${ }^{63}$ If the date of trial were the applicable time, then Wiltwyck, in making a purchase, would have to find a site which was not restricted and would not become so. And the court, in passing on the validity of a zoning ordinance enacted after the purchase, would have to decide whether there were alternate sites which were presently unrestricted and which would remain so. ${ }^{64}$ A rule which necessitates predicting the responses of each of many communities to Wiltwyck's efforts to purchase places an impossible burden both on the purchaser and on the court. It seems much more sensible to make the time of title passage the cut off point determining whether there were alternate available unrestricted sites. ${ }^{65}$ Even if the date of purchase is deemed the proper time to apply the above rule, a municipality may still contend that it has the power to frustrate, by its zoning

60. This principle has been applied by the courts in public utilities cases in determining whether there was reasonable necessity in the choice of site. See In re Hackensack Water Co., 41 N.J. Super. 408, 426 (App. Div. 1956) (dictum).

61. This issue was raised by appellant's attorney in objecting to the testimony of an expert witness on the subject of alternate available sites :

Mr. Liese: But then the witness would have to say that he knows that if any, a particular community where if we purchase land and let the public know that we are coming in with Wiltwyck, they would welcome us with open arms and wouldn't amend their zoning ordinance the way they did in this case.

***

The Court: I do believe it's apparent that we're dealing with an exact subject and exact science. Human beings will react the same no matter where you go. You never can tell how they're going to react. They will not say to you in East Burlap "We would love to have you here" and put you there but on the other hand, they Record, p. 271. might say, "We are going to change this ordinance."

62. Letter from Harry G. Liese to Yale Law Journal, December 13, 1961. (On file in Yale Law Library.)

63. See text accompanying notes 16,17 supra.

64. See note 61 supra.

65. An additional reason may be given for considering the "alternate site" rule as applicable at time of title passage and not at a subsequent date. A charitable institution will, with relative ease, be able to secure a conditional sales agreement making execution of the sales contract dependent on the use's still being a permitted one under the zoning ordinance as of the time of title passage. It is extremely unlikely, however, that a seller will agree to stand as guarantor against all future changes in the zoning law unless the buyer possesses extraordinary economic leverage on the seller. 
ordinance, the purpose for which the land was bought so long as it does not deprive the owner of a reasonable financial return on his land. ${ }^{66}$ The courts reply to this contention by viewing a zoning ordinance which totally frustrates the purpose for which the land was purchased as being confiscatory in the case of non-profit institutions ${ }^{67}$ though not in the case of the normal property owner. Apparently, the courts are willing to impute a profit motive to nearly all property owners, whether or not such a motive in fact exists. In the case of non-profit institutions, however, the courts appear unwilling to impute a profit motive ${ }^{68}$ and will not inquire whether the zoning ordinance in any way lowers the market value of their land. ${ }^{89}$ Since the land was bought to fulfill a

66. Frustration of purposes was alleged by the appellant in the Euclid case, sipra note 1 , and is likely to transpire as a result of nearly any zoning ordinance.

67. See, e.g., the court's statement in Long Island University v. Tappan, 202 Misc. $956,960,113$ N.Y.S.2d 795, 799 (1952) :

Insofar as the zoning ordinance seeks to prohibit entirely the use of plaintiff's lands in the village for the purposes for which it is chartered, the zoning ordinance is void and ineffectual, as beyond the power of the village board to enact and as bearing no reasonable relation to the promotion of the health, safety, morals or general welfare of the community. (Emphasis added).

See also cases cited note 6 supra. Since the purpose of holding land in the case of a nonprofit institution is generally not to sell it and realize a profit or reasonable financial return, an ordinance which prevents use of the land for charitable, service purposes is more nearly confiscatory in its effect. For this reason an ordinance which deprives a charitable nonprofit organization of the opportunity to use its land to render services will be invalid-while an ordinance which bars institutions carrying on the same services but for gain will be sustained as a valid exercise of the police power. City of Champaign v. Roseman, 15 IIl. $2 \mathrm{~d}$ 363, 155 N.E.2d 34 (1958) ; York Harbor Village Corp. v. Libby, 126 Me. 537, 140 Atl. 382 (1928) ; McCarter v. Beckwith, 247 App. Div. 289, 285 N.Y. Supp. 151 (1936) ; Dunkirk Aerie v. City of Dunkirk, 274 App. Div. 685, 87 N.Y.S.2d 202 (1949) ; Lawrence v. Nissen, 173 N.C. 359,91 S.E. 1036 (1917).

68. If, however, the land, though owned by a non-profit institution, was to be used for a profit-making venture that would supply income to the non-profit institution, frustration of purpose would not be sufficient. Cf. INT. REv. CoDE of 1954, $\$$ 502, 511-15 which deny tax-exempt status to "feeder organizations" (organizations operated primarily to carry on a trade or business for profits for the benefit of a tax exempt organization). Even without these code provisions, the courts have denied tax exempt status to such businesses. Ralph H. Eaton Foundation v. Comm'r, 219 F.2d 527 (9th Cir. 1955) ; contra, C. F. Mueller Co. v. Comm'r, 190 F.2d 120 (3d Cir. 1951).

69. See Concordia Collegiate Institute v. Miller, 301 N.Y. 189, 196-97, 93 N.E.2d 632, 636 (1950) where the court rejected the contention that

petitioner could obtain relief upon a proper showing of hardship .... Petitioner's property is in a residence zone, and it frankly concedes-what is in fact evident-that it cannot demonstrate that its land will not yield a reasonable return if used only for the purpose allowed in that zone, namely, for residences. Therefore, it asserts, it could not obtain a variance on the ground of hardship under our decisions, . . . and even if the board of appeals should grant its application, the variance would be a nullity, and by no means immune from attack by owners of adjoining property.

In short, petitioner urges that it should not be compelled to seek as a matter of grace and special privilege what at best is an extremely unlikely result, in the face of 
service function, a zoning ordinance preventing such use has been deemed confiscatory. ${ }^{70}$

\section{Detriment To The Community}

It may be conceded that many institutional uses are not ideal neighbors, depress surrounding property values, and deprive the municipality of needed tax revenues. ${ }^{71}$ In considering the resulting detriment to the community, courts appear to distinguish between unusual detrinent-those undesirable effects which would result from the interaction of the use with unique environmental conditions in the neighborhood where it proposes to locate-and customary detriment-those undesirable effects which invariably attend the presence of churches, hospitals, schools and the like. ${ }^{72}$ Courts disregard the customary detriment which attends the presence of such institutions in the community on the grounds that this detriment is merely an inevitable social cost of the highly valued and indispensable services which they render. ${ }^{73}$ So

an invalid statute that stands in the way of relief as a matter of right .... (Emphasis added.)

For this same reason, the variance, when based solely on hardship, is not a remedy available to non-profit institutions who do not allege that they have been deprived of the possibility of obtaining a reasonable financial return on their land. Variances may be granted only where the property, not the owner, is subjected to hardship; the fact that some unique circumstance personal to the owner makes the property unusable by him as restricted does not authorize a variance. Gold v. Zoning Bd. of Adjustment, $393 \mathrm{~Pa} .401,143$ A.2d 59 (1958) ; Carney v. City of Baltimore, 201 Md. 130, 93 A.2d 74 (1952); In re Kline, 395 Pa. 122, 148 A.2d 915 (1959). See generally Reps, Discretionary Powers of the Board of Zoning Appeals, 20 LAw \& Contenr. Pros. 280, 282-89 (1955).

70. See note 67 supra.

71. These and other detrimental effects were all presented in Diocese of Rochester v, Planning Bd., 1 N.Y. 2d 508, 136 N.E.2d 827, 154 N.Y.S.2d 849 (1956) and collectively rejected by the court as insufficient grounds for barring a religious use "clearly in furtherance of ... the general welfare." See also cases cited in notes 3,4 supra.

72. In Diocese of Rochester v. Planning Bd., 1 N.Y. $2 \mathrm{~d}$ at 526, 154 N.Y.S.2d at 863, the New York Court of Appeals said:

That is not to say that appropriate restrictions may never be imposed with respect to a church and school and accessory uses, nor is it to say that under no circumstances may they ever be excluded from designated areas.

Simultaneously the Court rejected allegations of traffic hazards, loss of tax revenues, decline in property values and decreased enjoyment of neighboring property as sufficient reasons for excluding a church. See also Roman Catholic Archbishop v. Baker, 140 Ore. 600, 610, 15 P.2d 391, 394 (1932) :

The reasons given for this decrease in value will apply with equal force to any other residential district, either of the first ar second class.

73. We do not believe it is a proper function of government to interfere in the name of the public to exclude churches from residential districts for the purpose of securing to adjacent landowners the benefits of exclusive residential restrictions.

State $c x$ rcl. Synod of Ohio v. Joseph, 139 Ohio St. 229, 39 N.E.2d 515, 524 (1942). Nonetheless it is still possible to inquire why the costs of charitable enterprises such as churches, schools, etc., should not be borne by those institutions rather than shifted to the unfortunate 
long as some neighborhood or community must bear this detriment, no single community is entitled to rid itself of the burden by simply shifting it to another. However, if a showing of unusual detriment is made by the community, the exclusionary provision may be sustained. The following fact situations might warrant a finding of unusual detriment. Example 1: A private hospital purchases property in an area of special historic interest with narrow, picturesque streets. The town argues that the streets cannot accommodate the projected increase in traffic which the new use will generate. Example 2: Wiltwyck tries to locate in a town where another institution charged with the care and reformation of delinquent boys (or girls) already exists. The town argues that the concentration of these two groups in a confined area might result in undesirable interaction. ${ }^{74}$ Example 3: A private school purchases an estate in an exclusive residential neighborhood where several other institutional uses have previously located. The town argues that its dearth of desirable residential land is critical and that the presence of one additional institutional use will change the residential character of the neighborhood. This might be conceptualized as an instance in which the cumulative effect of the customary detriment caused by individual institutions has created a situation in which unique detriment will accompany the location of one additional institution.

An analysis of these considerations accomplishes the following results: it weeds out those uses which cannot initially show sufficient injury to warrant invalidation of the ordinance; and it enables the court to determine when a municipality can justifiably zone against a larger public interest. As such, it is within the competency of courts to make this kind of analysis. It allows them to focus on the uniqueness of the detriment alleged by the community without requiring a comprehensive knowledge of available land resources or involving the exercise of planning expertise.

neighbors. In the context of charitable immunity to tort liability, one commentator has pointed out that

Resource allocation applies equally well to charitable institutions as to profit making enterprises. A charity sells itself just as any other service does. What it accomplishes in good works is its production. Its success depends on the desirability of those works, in the eyes of donors and others who pay for the charity's services, in comparison with the costs the works entail. A rational choice among charities, and between charities and other services requires that all the costs be before the public.... [T] here is no more reason for injured parties to pay the subsidy in the case of charities than there would be in other similarly situated industries.

Calabresi, Some Thoughts on Risk Distribution and the Law of Torts, 70 YALE L.J. 499, 548-49 (1961). The author concedes that because of considerations of administrative feasibility, the principles of enterprise liability may be applicable only in theory and not in practice to non-tort situations. Id. at 532-33.

74. This situation actually occurred when Wiltwyck sought to locate in Dobbs Ferry where another institution for the rehabilitation of delinquents is situated. That institution joined with the town in opposing Wiltwyck's entry. Conversation with Harry G. Liese, attorney for Wiltwyck, December 13, 1961. 
Had these considerations been articulated in the Wiltwyck case, the arguments presented by Yorktown to sustain the zoning ordinance would not have appeared so persuasive. First, as contrasted with the exclusively psychiatric approach of child guidance clinics, Wiltwyck's physical plant and suburban surroundings are an integral part of its guidance program. ${ }^{75}$ This "environmental therapy"70 approach has received wide commendation. ${ }^{77}$ It would follow from this and from Wiltwyck's obvious need to locate near New York City ${ }^{78}$ that an exceptionally strong showing of "general environmental need" can be made. Second, Wiltwyck, as a non-profit institution which obtained legal title to land prior to the passage of the zoning amendment, ${ }^{70}$ can demonstrate specific need to locate in Yorktown. To deny Wiltwyck the right to use its property for the sole purpose for which it was purchased-namely, for carrying out its service function-should be deemed confiscatory by the court. And finally, the detriment which Yorktown fears will attend the presence of Wiltwyck should not be considered a sufficient ground for exclusion. Such detriment-possible injury to persons and property should any of the boys stray from Wiltwyck and potential decline in property values ${ }^{80}$ - would invariably accompany Wiltwyck's presence wherever it locates. It is therefore customary detriment and unless Yorktown can demonstrate umisual detriment, namely that Wiltwyck's presence in Yorktown will work significantly greater harm than would occur in any other suitable community, the amendment excluding Wiltwyck should be invalidated.

75. See text accompanying note 12 supra.

76. Petitioner-Appellant's Brief, p. 8.

77. Mr. Hugh Pomeroy, a zoning expert who was a witness for Yorktown said of Wiltwyck:

[I]t is an institution characterized by nobility of purpose, by competence of operation and by excellence of accomplishment, and we regard its work as having deep humanitarian motivations and of substantial importance.

Record, p. 258. See also McCord \& McCord, Psychopathy and Deminguency (1956); McCord \& McCord, Two Approaches to the Cure of Delinquests, 44 J. CRIM. L., C. \& P.S. 442 (1953) (analysis of the Wiltwyck program).

78. See note 13 supra and accompanying text.

79. See note 17 supra and accompanying text. This fact amongst others distinguishes the Wiltwyck case from Matter of Jewish Mental Health Soc'y v. Village of Hastings, 268 N.Y. 458, 198 N.E. 30 (1935), affirming 243 App. Div. 707, 277 N.Y. Supp. 989, appeal dismissed, 297 U.S. 696 (1935), on which the court and Yorktown relied heavily. In the Hastings case, the ordinance making consent of the local board of health a prerequisite to the erection of any hospital, had been enacted prior to the purchase of the property. For an extended treatment of the features distinguishing the Wiltwyck and Hastings cases, see Judge Kleinfeld's dissent, 14 App. Div. 2d 198, 219 N.Y.S.2d 161, 189 (1961).

80. Record, pp. 169-71, 176-77, 183-84, 247-54. 